\title{
Influence of Repeated Loading and Geosynthetic Reinforcement on Base Course Thickness over Soft Soil
}

\author{
Slamet Widodo ${ }^{1}$, Shen Hong ${ }^{2}$, Abdelazim Ibrahim ${ }^{3}$ \\ Technisce Universität Bergakademie Freiberg, Gustav Zeuner Strasse 1, Freiberg(Sachsen), 09599, Germany \\ E-mail: ${ }^{1}$ slamet@engineer.com; slamet.widodo@student.tu-freiberg.de \\ ${ }^{2}$ shenhong84@163.com; shen@mailserver.tu-freiberg.de \\ 3abdelazimi@yahoo.com; abdelazim.ibrahim@student.tu-freiberg.de
}

\begin{abstract}
Vehicle wheels at surface of pavement will pass through it many times. Pavement or base course over soft soil always needs a reinforcement. Influence of repeated loading to thickness of base course and base course reinforced by geosynthetic is presented. Several existing methods as Giroud-Han, USA Corps of Engineers and DuPont Typar method respectively to calculate thickness of base course over soft soil using reinforcement material either geotextile or geogrid is presented and the influence of repeated loading will be compared. Results from calculation and analysis indicate that Giroud-Han method gives thickness of base course higher than other methods when CBR values of subgrade at least $2 \%$.
\end{abstract}

Keywords - Base course; geosynthetic; repeated loading; reinforcement; soft soil.

\section{INTRODUCTION}

Loading at surface of pavement is repeated loading. It will be distributed at the surface of subgrade layer. When subgrade is soft soil, reinforcement using geosynthetics are usual be done as a treatment. Type of reinforcement for soft soil is restraint subgrade whereas reinforcement for base course is base course reinforcement. Influence of repeated loading over pavement reinforced geosynthetic at surface of subgrade is presented. Subgrades having low bearing capacity lower than CBR $3 \%$ is poor soil even soft soil. Bearing capacity of subgrade can also use another parameter namely undrained shear strength $(\mathrm{Cu})$. The soil is soft soil when $\mathrm{Cu}$ value is lower than $25 \mathrm{kPa}$.

Because of repeated loading, thickness of base course becomes higher than only subjected by static loading. Soil reinforcement using geosynthetic material (geotextile and/or geogrid) accommodated in some methods as Giroud-Han, USA Corps of Engineers and DuPont Typar method respectively, but they give divergence results. For instance USA Corps of Engineers is applied for low traffic originally in the forest region particularly in USA and did not accommodate the repeated loading and DuPont Typar method only focuses on reinforcement using geotextile. Otherwise Giroud-Han method offers for design of soil reinforcement using both geotextile and geogrid and also accommodate the repeated loading of vehicles. The last method is a improvement of previous one so-called GiroudNoiray method [1].

In some parts in the world are covered by soft soils either peat or organic soil. In south east of Asia for peat soil there is more or less 20 million hectares and in Indonesia almost 30 percent of land area was covered by soft soil comprising of peat and organic soil [2]. Use of geosynthetic can increase the bearing capacity of base course at top surface for case of soil improvement and on the other hand it can also reduce the thickness of base course for case of base course reinforcement [3].

\section{LITERATURE REVIEW}

Some researchers have given formulas to the bearing capacity of soil based on unconfined compressive strength and/or undrained shear strength as a parameter. Although other parameters like CBR or R-value is often met in the pavement design

\subsection{Bearing Capacity of Soft Soil}

Bearing capacity for soft soil can be revealed as $\mathrm{CBR}, \mathrm{Cu}$ and qu. Bearing capacity for soil without confining pressure is :

$$
\mathrm{qu}=2 \cdot \mathrm{Cu}
$$


Before a complete failure of soil subgrade occurs, localstressing in shear takes place and results in punching shear failure or local failure in the soil. The bearing capacity of the subgrade under such conditions is low and can be quantified by

$$
\mathrm{qu}=\alpha \cdot \mathrm{Cu}
$$

When localized shear failure of the subgrade can be prevented in the case any reinforcement for soil (i.e. a general shear failure can be reached), the bearing capacity of the subgrade can be increased to

$$
\mathrm{qu}=\beta . \mathrm{Cu}
$$

Several methods give value of $\alpha$ and $\beta$ as shown Table 1 .

TABLE 1

BEARING CAPACITY OF SUBGRADE

\begin{tabular}{|l|l|l|}
\hline \multicolumn{1}{|c|}{$\begin{array}{c}\text { Researchers and/or } \\
\text { Sources }\end{array}$} & Unreinforced & Reinforced \\
\hline $\begin{array}{l}\text { Giroud and Noiray (1981) } \\
\text { Barenberg (1992) }\end{array}$ & $\begin{array}{l}\mathrm{qu}=3.14 \mathrm{Cu} \\
\text { Philips (1987) }\end{array}$ & $\mathrm{qu}=5.14 \mathrm{Cu}$ \\
Rodin (1965) & $\mathrm{qu}=2.8 \mathrm{Cu}$ & $\mathrm{qu}=6 \mathrm{Cu}$ \\
DuPont Typar SF (2010) & $\mathrm{qu}=3.14 \mathrm{Cu}$ & $\mathrm{qu}=6.2 \mathrm{Cu}$ \\
Roadex III (2008 ) & $\mathrm{qu}=4.14$ & $\mathrm{qu}=(2+\pi) \mathrm{Cu}$ \\
\hline
\end{tabular}

Empirical relation between CBR value and undrained shear strength can be used if subgrade value is provided :

$$
\mathrm{Cu}=30 . \mathrm{CBR}
$$

Many conventional pavement design methods can be applied when subgrade has CBR value minimum $3 \%$. In this paper, Austroads (1992) using chart method to calculate thickness of base course is presented as a comparison with other methods.. The method presents thickness of unreinforced base course. Minimum CBR value for subgrade in this design method is $2 \%$. It is impossible to design thickness of pavement if subgrade has the bearing capacity (CBR value) below $2 \%$ as shown in Figure 1.

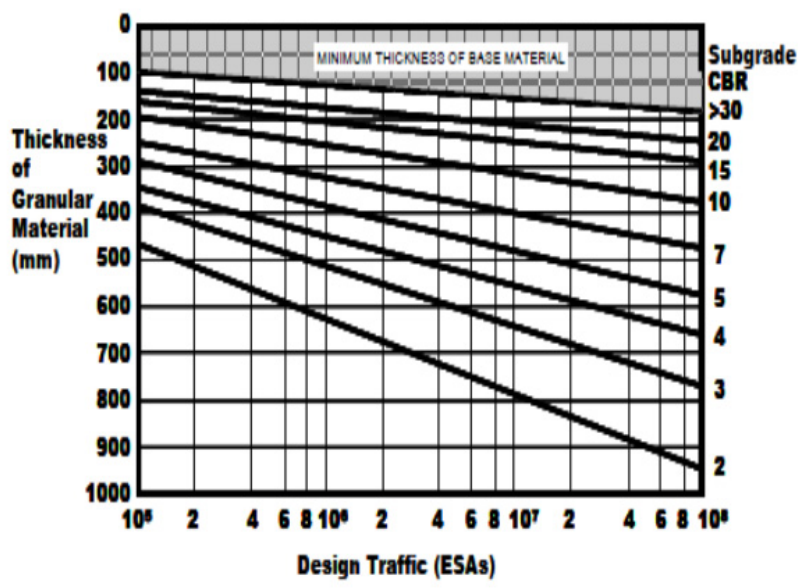

Fig. 1 Pavement thickness chart for thin-surface granular [4]

\subsection{Geosynthetic reinforcement}

J.P. Giroud and Jie Han (2004) published a design method in the August edition of the American Society Civil Engineers ([1],[7]).

$$
h=\frac{0.868+\left(0.661-1.006 J^{2}\right)\left(\frac{r}{h}\right)^{1.5} \log N}{\left[1+0.204\left(\frac{3.48 C B R_{h c}^{0.3}}{C B R_{g g}}-1\right)\right]}\left(\sqrt{\frac{s}{f_{s}\left[1-0.9 e^{\left.-\left(\frac{r}{h}\right)^{2}\right]}\right] N_{c} f_{c} C B R_{g g}}}-1\right) r
$$

where:

$\mathrm{Nc}=3.14$ and $\mathrm{J}=0$ for unreinforced base course

$\mathrm{Nc}=5.14$ and $\mathrm{J}=0$ for geotextile-reinforced base course

$\mathrm{Nc}=5.71$ and $\mathrm{J}=0.32 \mathrm{~m}-\mathrm{N} /$ degree for Tensar BX 1100 reinforced base course

$\mathrm{Nc}=5.71$ and $\mathrm{J}=0.65 \mathrm{~m}-\mathrm{N} /$ degree for Tensar BX 1200 reinforced base course

In February 2003, the Corps of Engineers published a design method consideration the use of geogrids and geotextiles for paved and unpaved roads [1]. Its approach for unpaved surface based on methodology originally by US Forest Service, distinguishes the performance of geogrids and geotextiles as reinforcement component. Bearing capacity factor, $\mathrm{Nc}$, for the geosynthetic type being considered. The corps recommended the following $\mathrm{Nc}$ values: $\mathrm{Nc}=2.8$ without a geosynthetic, $\mathrm{Nc}=3.6$ with a geotextile for conservative designs an $\mathrm{Nc}=5.8$ with a geogrid.

The in situ shear strength can be measured directly using vane shear devices or indirectly using bearing capacity correlation from California Bearing ratio (CBR) or Dynamic Cone Penetrometer (DCP) tests. The $75^{\text {th }}$ percentile strength is the value at which 75 percent of recorded soil strength readings are higher than this value. Figure 2 can be used to convert design strength from cone index values and CBR to shear strength ( C) in psi.
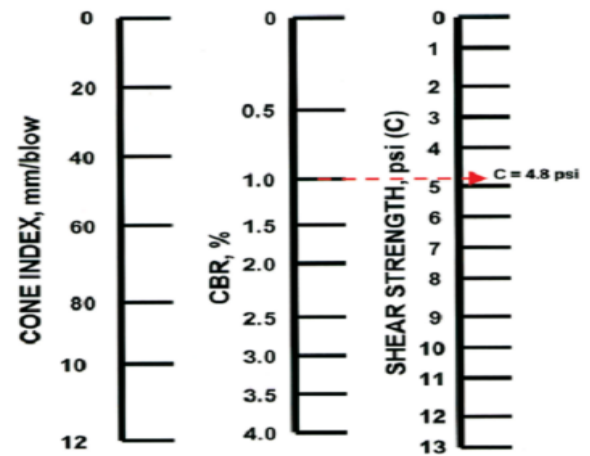

Fig. 2 Relationship between cone index,CBR and shear strength [5]

$$
\text { Subgrade bearing capacity }=\mathrm{C} . \mathrm{Nc}
$$

This method uses graphical way to determine thickness of reinforced base course depending on wheel configuration. 
DuPont Typar SF [5] presents a design method using geotextile to calculate thickness of reinforced base course. Bearing capacity for soft soil can use the correlation chart for estimating the subgrade CBR value as Figure 3 below.

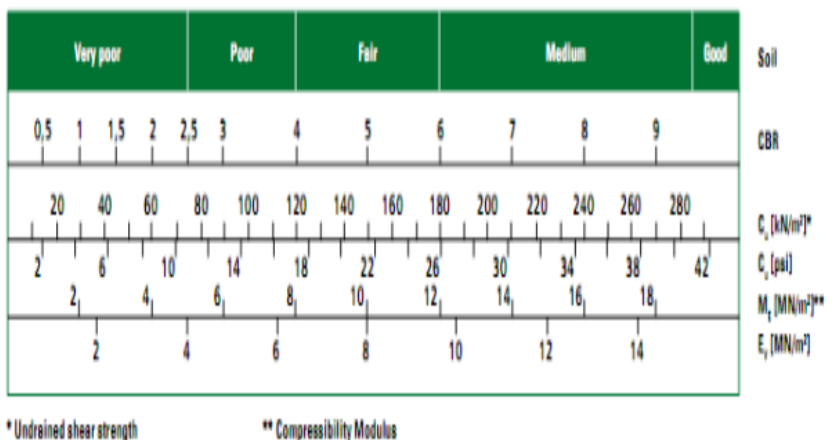

Fig. 3 Correlation chart for estimating the subgrade CBR value [6]

Factors to determine To using this method as shown in Table 2 and thickness of base course for To is equal to repetition 1000 times.

TABLE 2

FACTORS TO DETERMINE TO [5]

\begin{tabular}{|c|c|c|}
\hline CBR [\%] & $P,[k N]$ & $P_{2}$ [lbs] \\
\hline $\begin{array}{c}0,5 \\
1 \\
1.5 \\
2 \\
3 \\
4 \\
5 \\
6 \\
7 \\
8 \\
9 \\
10\end{array}$ & $\begin{array}{l}45.31 \\
32.37 \\
25.89 \\
22.47 \\
20.56 \\
18.66 \\
17.14 \\
16.00 \\
14.85 \\
13.71 \\
12.95 \\
12.19\end{array}$ & $\begin{array}{l}0.119 \\
0.085 \\
0.068 \\
0.059 \\
0.054 \\
0.049 \\
0.045 \\
0.042 \\
0.039 \\
0.036 \\
0.034 \\
0.032\end{array}$ \\
\hline \multicolumn{3}{|c|}{$T_{0}(\mathrm{~mm})=P, \sqrt{A x l e} \operatorname{Load}(\mathrm{kN})$} \\
\hline
\end{tabular}

Thickness of reinforced base course using this method is

$$
\begin{aligned}
& \mathrm{T}=\mathrm{C} \cdot \mathrm{To}=\left(0.27 \log \left(\sum \mathrm{Ni} . \mathrm{ESAL}\right)+0.19\right) \mathrm{To} \\
& \mathrm{ESAL}=(\mathrm{Pi} / \mathrm{Po})^{3.95} \\
& \mathrm{Ne}=\Sigma \mathrm{Ni} . \mathrm{ESAL}
\end{aligned}
$$

\section{CAlculation of BAse COURSE Thickness}

Thicknesses of base courses using input parameters for reinforced and unreinforced base courses which subjected by repeated loading with some methods are presented.

\subsection{Input Data for Calculation}

Input data for calculation using several design methods to calculate thickness of base course without reinforcement and with reinforcement are needed. Input data comprise of axle load, wheel configuration, bearing capacity of subgrade, number of load passing. Input data used in this calculation as presented in Table 3 below.
TABLE 3

MAIN INPUT DATA FOR CALCULATION

\begin{tabular}{|l|l|l|}
\hline \multicolumn{1}{|c|}{ Input Data } & \multicolumn{1}{|c|}{ Value } & \multicolumn{1}{c|}{ Unit } \\
\hline Standar Axle load & 80 & KN \\
Tire pressure & 82 & psi \\
Number of passes & 1 to 1.000 .000 & - \\
Base course strength & CBR 80 & $\%$ \\
Subgrade strength & CBR 0.5 to 4 & $\%$ \\
Radius of tire contact & 15 & centimeter \\
Rut depth & 50.8 & milimeter \\
\hline
\end{tabular}

\subsection{Thickness of Base Course}

Calculations for thickness of base course using several methods both reinforced and unreinforced are presented in Table 4(a) to 4(c) below. These tables comprise of three kind of analysis i.e., thickness of unreinforced base course, thickness of geotextile reinforced base course and thickness of geogrid reinforced base course.

\begin{tabular}{|c|c|c|c|c|c|c|c|c|}
\hline \multirow{3}{*}{$\begin{array}{c}\text { CBR } \\
\mathbf{s g} \\
(\%)\end{array}$} & \multicolumn{8}{|c|}{ Thickness of Unreinforced Base Courses for $\mathbf{N}$ in $\mathbf{m m}$} \\
\hline & \multicolumn{2}{|c|}{$\begin{array}{l}\text { Austroads } \\
\text { Method }\end{array}$} & \multicolumn{4}{|c|}{ Giroud Han Method } & \multirow{2}{*}{$\begin{array}{c}\text { USACoE } \\
\text { Method } \\
\mathrm{N}=1\end{array}$} & \multirow{2}{*}{$\begin{array}{c}\begin{array}{c}\text { DuPont } \\
\text { Typar } \\
\text { SF }\end{array} \\
\mathrm{To}=> \\
\mathrm{N}=10^{3}\end{array}$} \\
\hline & $10^{5}$ & $10^{6}$ & $\mathrm{~N}=1$ & $10^{3}$ & $10^{5}$ & $10^{6}$ & & \\
\hline 0.5 & $>470$ & $>625$ & 120 & 383 & 462 & 494 & 686 & 405 \\
\hline 1 & $>470$ & $>625$ & 170 & 467 & 548 & 58 & 50 & 28 \\
\hline 1.5 & $>470$ & $>625$ & 199 & 502 & 584 & 617 & 432 & 232 \\
\hline 2 & 470 & 625 & 200 & 514 & 597 & 630 & 35 & 201 \\
\hline 2.5 & 430 & 580 & 190 & 516 & 599 & 633 & 317 & 192 \\
\hline 3 & 390 & 510 & 166 & 510 & 595 & 628 & 279 & 184 \\
\hline 3.5 & 370 & 485 & 138 & 444 & 588 & 620 & 254 & 175 \\
\hline 4 & 350 & 450 & 119 & 432 & 578 & 610 & 229 & 167 \\
\hline
\end{tabular}

TABLE 4 (A)

THICKNESS OF UNREINFORCED BASE COURSES

Table 4 (b) and Table 4 (c) indicate the thickness of base course using reinforcement of geotextile and geogrid respectively for several methods as previously mentioned.

TABLE 4 (B)

THICKNESS OF REINFORCED BASE COURSES USING GEOTEXTILE

\begin{tabular}{|c|c|c|c|c|c|c|c|c|c|}
\hline \multirow{2}{*}{$\begin{array}{c}\text { CBR } \\
\text { sg } \\
(\%)\end{array}$} & \multicolumn{9}{|c|}{ Thickness of BaseCourses Using Geotextile for N in } \\
mm \\
\cline { 2 - 9 } \\
\cline { 2 - 9 } & USACoE & \multicolumn{7}{|c|}{ Giroud Han Method } & \multicolumn{3}{c|}{ DuPont Typar SF } \\
\cline { 2 - 9 } & $\mathrm{N}=1$ & $\mathrm{~N}=1$ & $10^{3}$ & $10^{5}$ & $10^{6}$ & $\mathrm{~N}=1$ & $10^{3}$ & $10^{5}$ & $10^{6}$ \\
\hline 0.5 & 635 & 80 & 290 & 365 & 394 & 77 & 405 & 624 & 733 \\
1 & 432 & 90 & 346 & 426 & 458 & 55 & 289 & 446 & 524 \\
1.5 & 343 & 90 & 366 & 449 & 482 & 44 & 232 & 357 & 419 \\
2 & 305 & 84 & 370 & 455 & 489 & 38 & 201 & 309 & 364 \\
2.5 & 254 & 78 & 366 & 453 & 486 & 36 & 192 & 296 & 348 \\
3 & 229 & 71 & 357 & 445 & 479 & 35 & 184 & 283 & 333 \\
3.5 & 203 & 66 & 345 & 435 & 470 & 33 & 175 & 270 & 317 \\
4 & 191 & 58 & 331 & 423 & 458 & 32 & 167 & 257 & 302 \\
\hline
\end{tabular}


TABLE 4 (C)

THICKNESS OF REINFORCED BASE COURSES USING GEOGRID

\begin{tabular}{|c|c|c|c|c|c|c|c|c|c|}
\hline \multirow{4}{*}{$\begin{array}{c}\text { CBR } \\
\text { sg } \\
(\%)\end{array}$} & \multicolumn{9}{|c|}{ Thickness of Base Courses Using Geogrid for $\mathbf{N}$ in $\mathbf{m m}$} \\
\hline & \multicolumn{8}{|c|}{ Giroud-Han Method } & \multirow{3}{*}{$\begin{array}{c}\begin{array}{c}\text { USACoE } \\
\text { Method }\end{array} \\
\mathrm{N}=1\end{array}$} \\
\hline & \multicolumn{4}{|c|}{$\begin{array}{c}\text { Geogrid Uniaxial } \\
\text { TX110 }\end{array}$} & \multicolumn{4}{|c|}{$\begin{array}{l}\text { Geogrid Biaxial } \\
\text { BX220 }\end{array}$} & \\
\hline & $\mathrm{N}=1$ & $10^{3}$ & $10^{5}$ & $10^{6}$ & $\mathrm{~N}=1$ & $10^{3}$ & $10^{5}$ & $10^{6}$ & \\
\hline 0.5 & 74 & 253 & 321 & 350 & 74 & 171 & 215 & 234 & 483 \\
\hline 1 & 82 & 300 & 375 & 405 & 82 & 202 & 255 & 278 & 305 \\
\hline 1.5 & 80 & 316 & 395 & 426 & 80 & 209 & 268 & 292 & 228 \\
\hline 2 & 75 & 317 & 398 & 430 & 75 & 205 & 268 & 293 & 190 \\
\hline 2.5 & 69 & 310 & 394 & 427 & 69 & 194 & 259 & 286 & 152 \\
\hline 3 & 63 & 301 & 386 & 418 & 63 & 179 & 246 & 274 & 100 \\
\hline 3.5 & 56 & 286 & 374 & 407 & 56 & 163 & 230 & 259 & 89 \\
\hline 4 & 50 & 271 & 361 & 395 & 50 & 146 & 214 & 243 & 89 \\
\hline
\end{tabular}

\section{RESULTS AND DISCUSSIONS}

\subsection{Bearing Capacity}

Bearing capacity for very poor soil using Barenberg chart is lower than CBR $2.5 \%$ and poor soil between 2.5 and $4 \%$ in CBR value. Bearing capacity in several methods use undrained shear strength $(\mathrm{Cu})$ therefore empirical relation for $\mathrm{CBR}$ value and $\mathrm{Cu}$ value have to be taken. Undrained shear strength is taken 30 times CBR value.

\subsection{Thickness of Base Course}

From Table 4 above can be depicted the trend line in other to give illustration better. Thickness of unreinforced base course from three methods namely Austroads, Giroud-Han and US Army Corps of Engineer respectively as shown in Figure 4.

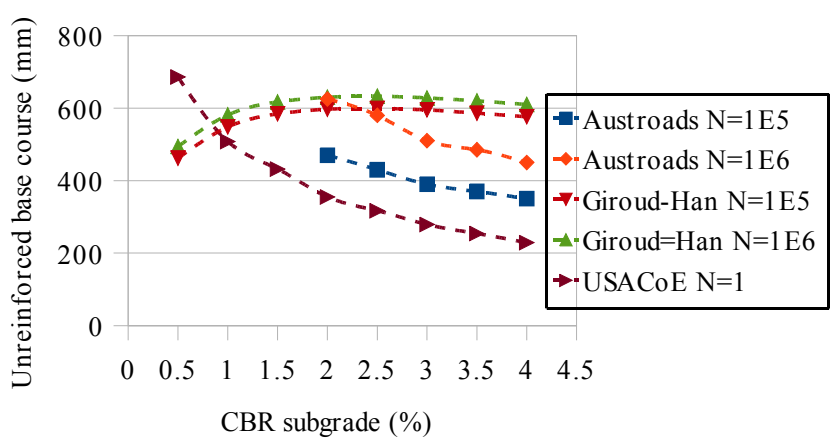

Fig. 4 Thickness of unreinforced base course

Thickness of unreinforced base course using US Army method is lowest for CBR subgrade value more than $2 \%$. Thickness base course using Giroud-Han method is highest but for CBR subgrade values lower than $2 \%$ indicate wrong trend line because softer subgrades will need thicker base course layers. Thickness resulted from Giroud-Han is higher than thickness using Austroads method for the same number of repetition $\mathrm{N}=1 \mathrm{E} 5$ and $\mathrm{N}=1 \mathrm{E} 6$.
Thickness of geotextile reinforced base course from three methods namely Giroud Han , US Army, DuPont Typar as shown in Figure 5.

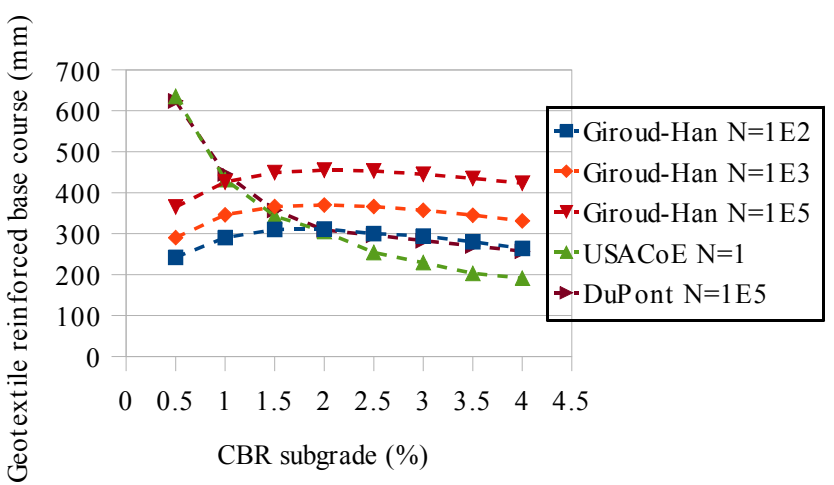

Fig. 5 Thickness of geotextile reinforced base course

Thickness of geotextile reinforced base course using USArmy Corps of Engineer is lowest. In contrary, GiroudHan method gives the highest. It is interesting that the thickness for CBR subgrade values more than $2 \%$ between the method of DuPont N=1E5 and Giroud-Han method $\mathrm{N}=1 \mathrm{E} 2$ superimposes each other whereas $\mathrm{CBR}$ subgrade values lower than $2 \%$ between US Army Corps of Engineer and DuPont Typar SF N=1E5. Furthermore, Giroud-Han method gives wrong trend line for CBR subgrade lower than $2 \%$.

Thickness of geogrid reinforced base course from three methods namely Giroud-Han, US Army Corps of Engineer, DuPont Typar as depicted in Figure 6.

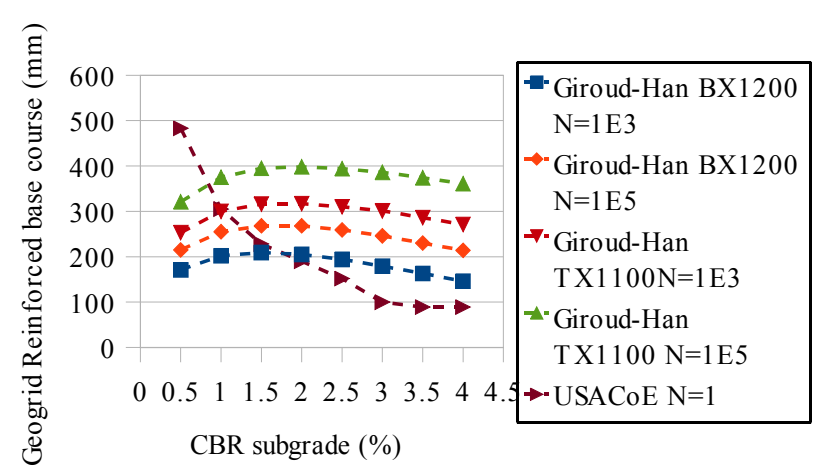

Fig. 6 Thickness of geogrid reinforced base course

Geogrid reinforcement for biaxial gives lower thickness of base course than uniaxial using Giroud-Han method. It is like previous trend line using Giroud-Han method indicates wrong trend line for CBR subgrade lower than $2 \%$. It is also similar trend line for US Army Corps of Engineers method that presents lowest result.

\section{CONCLUSIONS}

From description and explanation above that Giroud-Han method gives a design pavement method relatively safe than other for CBR subgrade value more than $2 \%$ and misleading when applied on lower CBR values of subgrade . US Army Corps of Engineer method actually be applied for low traffic 
volume so that gives lowest thickness of base course. Finally, Austroads method actually is not addressed for designing pavement on soft soil. Herein, it is aimed to make comparison when CBR subgrade at least $2 \%$ and more. Geogrid reinforcement give higher reduction of base course thickness than geotextile as well biaxial geogrid than uniaxial one.

\section{NOMENCLATURE}

$\begin{array}{lll}\mathrm{qu} & \text { unconfined compressive strength } & \mathrm{kPa} \\ \mathrm{Cu} & \text { undrained shear strength } & \mathrm{kPa} \\ \mathrm{CBR} & \text { california bearing ratio } & \% \\ \mathrm{~h} & \text { required base course thickness } & \mathrm{m} \\ \mathrm{J} & \text { geogrid aperture stability modulus } & \mathrm{m}-\mathrm{N} / \text { degre } \\ \mathrm{N} & \text { number of axle passes } & {[-]} \\ \mathrm{P} & \text { wheel load } & \mathrm{kN} \\ \mathrm{r} & \text { radius of equivalent tire contact area } & \mathrm{m} \\ \mathrm{s} & \text { allowable rut depth } & \mathrm{mm} \\ \mathrm{fs} & \text { factor equal to 75 mm } & {[-]} \\ \mathrm{Nc} & \text { bearing capacity factor } & {[-]} \\ \mathrm{C} & \text { cone index value } & {[-]} \\ \mathrm{T} & \text { thickness } & {[-]} \\ \mathrm{ESAL} & \text { equivalent single axle load } & {[-]} \\ \mathrm{Po} & \text { standard axle load } & 80 \mathrm{kN} \\ \mathrm{Pi} & \text { actual number of passes } & {[-]} \\ \mathrm{Ni} & \text { actual number of passes } & {[-]} \\ \mathrm{To} & \text { compacted crushed stone thickness } & \mathrm{m}\end{array}$

\section{Greek letters}

$\alpha \quad$ constant

$\beta \quad$ constant

$[-]$

\section{Subscripts}

$\begin{array}{ll}\text { sg } & \text { subgrade } \\ \text { bc } & \text { base course }\end{array}$

\section{ACKNOWLEDGMENT}

We would like to thank to Prof. H. Klapperich, Dr. Tandor Tamaskovics and my colleague Sebastian Altoff for valuable advice in geosynthetic.

\section{REFERENCES}

[1] S. Archer, (2008), Subgrade Improvement for Paved and Unpaved Surfaces Using Geogrids, Professional Development Series.

[2] Puslitbang,(2001), Panduan Geoteknik-4, Desain dan Konstruksi Puslitbang Prasarana Transportasi, WSP International.

[3] Tencate Mirafi (2010), Geosynthetic reinforcement of the aggregate base/subbase course of pavement structures, Technical Note, TenCate Geosyhnthetics North America.

[4] G.W. Jameson, (1996), Original of Austrroads design procedures for granular pavements, Research Report ARR 292, ARRB Transport Research.

[5] Technical Handbook (2010), DuPont Typar SF Introduction.

[6] E.J. Barenberg, (1992), Subgrade stabilization, in design primer: Geotextiles and related materials, IFAI,10-20.

[7] Tenax Corporation. (2001), Design of soft soil stabilization with Tenax geogrids, Technical reference GRID-DE-3. 